\title{
FACTORS AFFECTING VOLUNTARY DISCLOSURE WITH CORPORATE GOVERNANCE AS MODERATING VARIABLES
}

\author{
${ }^{1}$ Eny Widayawati, ${ }^{2}$ Moch. Dzulkirom and ${ }^{3}$ Ari Darmawan \\ ${ }^{1}$ Master of Business Administration, Faculty of Administrative Sciences \\ Brawijaya University, Malang, Indonesia \\ ${ }^{2,3}$ Faculty of Administrative Sciences \\ Brawijaya University, Malang, Indonesia
}

\begin{abstract}
Purpose - The purpose of this research is to analyze and prove the influence of independent variables that are proxied by profitability, liquidity, firm size on voluntary disclosure, and moderated by corporate governance variables.

Design/methodology/approach - The object of the research is the companies listed on the IDX from 2012 through 2016. This research uses a purposive sampling method involving 45 annual company reports and uses multiple regression and MRA (Moderated Regression Analysis) as a data analysis tool.

Findings - The results of this research indicate that there is a significant positive effect between liquidity, firm size on voluntary disclosure, there is a significant negative effect between profitability and voluntary disclosure, and corporate governance moderates the relationship between profitability, liquidity, firm size, and voluntary disclosure.

Practical Implications - Companies with high liquidity supported by good corporate governance will reduce voluntary disclosures due to the existence of independent commissioners whose positions are still less influential with the board of commissioners and board of directors, in the other hand, companies with low profitability supported by good corporate governance encourage managers to disclose company information more broadly to convince all stakeholders concerned.
\end{abstract}

Originality/value -

Keywords Profitability, Liquidity, Company size, Corporate governance, Voluntary disclosure.

Paper Type Research paper (secondary data) 


\section{INTRODUCTION}

Information in the business world is the main source of economic decision making. Information disclosure is an integral part of the company. Company information will be utilized by stakeholders, especially investors for business decision making. Companies that register their shares in the capital market face competition from other companies in terms of securities, terms, and returns offered. Investors need the information to estimate the uncertainty of cash flows in the future. The information submitted by the company is expected to meet all of the investors' needs (Hardiningsih, 2008).

Information disclosed by the company is divided into two, namely mandatory disclosure and voluntary disclosure. Disclosure of information must be carried out by the regulator to protect both local and foreign investors. In Indonesia, the obligation to convey information at a minimum in the annual report of companies listed on the Indonesia Stock Exchange is regulated in the Financial Services Authority (OJK) regulation No. 29 / POJK.04 / 2016 concerning annual reports of Issuers or Public Companies. Companies that do not meet the requirements in this regulation will be penalized. All open companies (Go Public) have made mandatory disclosures clearly and completely per applicable regulations. Meanwhile, voluntary disclosure is other information that is not regulated by the OJK so that it is freely carried out by the company. Voluntary disclosure is a free choice of company management to provide accounting information and other information that is deemed relevant for the decision making of users of its annual report. For example; summary financial data for 6 years or more, number of employees in the last 2 years, reasons for employee changes, information on regional political stability, financial and non-financial charts, consumer loyalty index, board image, other positions held by the board. Voluntary disclosure is expected to reduce the problem of information asymmetry that occurs between managers and shareholders (owners).

According to agency theory (Jensen \& Beckling, 1976) defines agency relations as a contract between the principal (shareowner) and the agent (manager) in the company. Agency theory raises information asymmetry, where managers have more information related to the condition of the company than the owner. The company will be encouraged by the owner to disclose more information regarding the condition of the company. Information disclosure is also a form of transparency and to avoid conflicts with stakeholders. According to signal theory (Ross, 1977), the existence of information asymmetry has encouraged managers to provide signals in the form of disclosure of information to investors related to competitive advantage to obtain funding from investors and improve the reputation of the company. Based on capital Need Theory (Choi, 1973), companies will always increase external funding both through liabilities and equity. Capital need theory explains that voluntary disclosure can help increase capital at a low cost. Investors will be more able to reduce the risk uncertainty of investments invested in the

Vol. 28, No. 01 April 2020

(C) Centre for Indonesian Accounting and Management Research Postgraduate Program, Brawijaya University 
company through the information disclosed, so as to reduce the premiums that must be paid to the investors.

In the Indonesian capital market, the level of company compliance with required disclosures is quite good. The results of Widjayanti's research (2015) found that the level of compliance with mandatory disclosures in Indonesia was $73 \%$. On voluntary disclosure, Oktaviani (2016) found that the average voluntary disclosure by manufacturing companies in the IDX for the 2014-2015 period was $39.83 \%$. These findings indicate that the phenomenon of voluntary disclosure in Indonesia is still low. The low level of voluntary disclosure does not only occur in Indonesia but is also experienced by several other developing countries, as found by Baroko (2007) in Kenya (11\% -20\%), Soliman (2013) in Egypt (31.92\%), Alshammari (2008) in Kuwait (15\%), Bhasin et al (2012) in Khazastan (24.95\%), Yuen et al (2009) in China (21.4\%), and Hammami and Hossain (2009) in Qatar $(36.84 \%)$.

This research examines factors that can influence voluntary disclosure with corporate governance as a moderating variable. Based on previous research, factors that are considered to influence voluntary disclosure are profitability, liquidity, and company size. Corporate governance is used as a moderating variable because the existence of good corporate governance will further encourage transparency carried out by issuers/companies.

High profitability can encourage management to make more voluntary disclosures. Voluntary disclosure is carried out to show investors the company's performance is good so that it can increase the value and reputation of the company in the market. Managers also have an interest in doing voluntary disclosure that is to gain personal gain. Good performance will encourage an increase in compensation that will be received by managers so that managers will tend to disclose private information as a form of justification for achieving performance. This statement is proven through research conducted by Baroko (2007) and Almilia (2008). While Al-Shammari (2008), Hammami and Hossain (2009), and Uyar Et al (2013) did not find the effect of profitability on voluntary disclosure.

Liquidity also plays a role in encouraging companies to disclose voluntary information. Both investors and creditors have an interest in the company's business continuity. Companies that are able to fulfill their short-term obligations well will try to convey more voluntary information as a form of accountability and signaling regarding the company's condition to the public. Voluntary disclosure is also able to attract other potential investors in the market. This factor is supported by research conducted by Baroko (2007). Panjaitan (2016) found no evidence of the influence of liquidity on voluntary disclosure.

Firm size can be an incentive for companies to do more voluntary disclosure because large companies tend to produce more information that other companies do not necessarily have. This added value will be an attraction for investors. The size of large companies also has large political costs. The threat of political costs that might be faced includes price controls, tighter arrangements, 
threats of nationalization, and corporate social responsibility issues. More voluntary disclosure is expected to be able to help companies to reduce criticism and negative issues that arise and give a good impression of the company to the public so that intervention from the government will decrease. Baroko (2007), Almilia (2008), AlShammari (2008), Mujiono and Nany (2010), Hammami and Hossain (2009), Soliman (2013) and Uyar et al. (2013) have proven this. Whereas Murcia and Santos (2010) revealed that the size of the company did not guarantee voluntary disclosure.

This research was motivated by Baroko's research (2007) by adding corporate governance variables as moderating variables. Corporate governance can encourage voluntary disclosure by the company. One characteristic of good corporate governance is the presence of independent commissioners. The existence of independent commissioners among the board of commissioners can encourage voluntary disclosure because it has more interest in the overall shareholders as well as high expertise and experience (Yuen et al., 2009; Akhtaruddin et al., 2009; Clemente and Labat, 2009; and Bahsin et al., 2012). The existence of an audit committee also has a positive effect on companies to make voluntary disclosures (Baroko, 2007). The function of the audit committee is to ensure the company has implemented internal controls, risk management, and good corporate governance.

\section{Voluntary Disclosure}

In business activities, investors need precise and accurate information to reach effective investment decisions. Information can be obtained through the disclosure of information by the company. Information disclosure is the release of information by companies both financial and non-financial in nature to stakeholders (Bhin, 2012).

Judging from the breadth, information disclosure is divided into three namely adequate, reasonable, and complete disclosure. Adequate disclosures imply a minimum number of disclosures that must be met in accordance with the purpose of making financial statements that are not misleading for decision making. Reasonable disclosure implies an ethical goal which is to provide equal treatment to all potential readers. Complete disclosure implies the presentation of all relevant information (Nuswandari, 2009).

Judging from the necessity of its delivery, information disclosure is divided into two namely mandatory disclosure and voluntary disclosure. Mandatory disclosure is information disclosure by an issuer that is governed by a country's regulations. In the Indonesian stock exchange, the disclosure must be regulated in OJK Regulation No.29 / POJK.04 / 2016 regarding Issuer's annual report. Whereas voluntary disclosure is the delivery of information that exceeds the minimum requirements of the regulations set by the capital market authority. 
Information can be obtained from various sources, one of which is an annual report. The annual report communicates financial and non-financial information to shareholders, creditors, the government, investors, and other interested parties (Baroko, 2007; Mujiono and Nany, 2010). The company will use its annual report which consists of mandatory and voluntary reports for shareholders and potential investors, as well as the government and the public. In the annual report, we can find mandatory disclosures and voluntary disclosures. The company has the discretion to make voluntary disclosures in annual reports so that the wide variations of voluntary disclosures between companies can vary (Nuswandari, 2009). The company will conduct an analysis of the costs and benefits of disclosure of information so that it can affect the extent of disclosure it does. Management is willing to disclose the information if the benefits derived from disclosing the information are higher than the costs (Mujiono and Nany, 2010). according to previous research, the extent of voluntary disclosure is influenced by the company characteristics, such as profitability, liquidity, company size.

\section{RESEARCH METHODS}

This research is using quantitative research, This research uses secondary data, namely historical data in the form of company annual reports and corporate governance perception index (CGPI) indexes. Annual report collection uses the location of the Indonesia Stock Exchange website (http://www.idx.co.id) in the form of the company's annual report for the period 2012-2016. Data on CGPI is obtained from the official website of the IICG (www.iicg.org).

The population in this research are companies listed on the Indonesia Stock Exchange for the period 2012-2016. The sampling method is purposive sampling, namely the formation of samples from the population-based on certain criteria (Sugiyono, 2011). Samples will be taken from the population with the following criteria:

1. Companies listed on the Indonesia Stock Exchange in 2012-2016

2. Companies included in the 2012-2016 IICG survey

3. Companies that participated in the IICG survey in a period of 2012-2016

From the results of purposive sampling obtained a sample of 9 companies over a period of 5 years, resulting in 45 data.z

The variables in this research are as follows:

Table 1: Indicators, Formulas, and Sources of Variable Operational Definitions

\begin{tabular}{|c|c|c|c|}
\hline Variable & Indicator & Formula & Source \\
\hline \multirow{2}{*}{$\begin{array}{l}\text { Profitability } \\
\text { (x1) }\end{array}$} & NPM & $\begin{array}{l}\text { earning after interest and tax } \\
\text { sales }\end{array}$ & \multirow{2}{*}{$\begin{array}{l}\text { Baroko, 2007; } \\
\text { Almalia, 2008; } \\
\text { Yuen et al., } \\
\text { 2009; Uyar et al., }\end{array}$} \\
\hline & ROA & $\frac{\text { net income after tax }}{\text { total assets }}$ & \\
\hline
\end{tabular}




\begin{tabular}{|c|c|c|c|}
\hline & ROE & $\frac{\text { Net profit }}{\text { Ekuitas }}$ & 2013 \\
\hline \multirow{3}{*}{$\begin{array}{l}\text { Liquidity } \\
\text { (X2) }\end{array}$} & $\mathrm{CR}$ & $\frac{\text { Current assets }}{\text { Current liabilities }}$ & \multirow[t]{3}{*}{ Baroko, 2007} \\
\hline & QR & $\begin{array}{l}\text { current assets-inventory } \\
\text { current liabilities }\end{array}$ & \\
\hline & CashR & $\begin{array}{l}\text { Current assets }- \text { (inventory }+ \\
\underline{\text { accounts receivable) }} \\
\text { current liabilities }\end{array}$ & \\
\hline \multirow[t]{3}{*}{$\begin{array}{l}\text { Company } \\
\text { Size } \\
\text { (X3) }\end{array}$} & TA & Log n Total Assets & $\begin{array}{l}\text { Baroko, 2007; } \\
\text { Almilia, 2008; } \\
\text { Bhasin et al, } \\
\text { 2011; Darmadi } \\
\text { dan Sodikin, } \\
\text { 2013; Soliman, } \\
2013\end{array}$ \\
\hline & $\mathrm{TP}$ & Log n Total Sales & \\
\hline & KP & Log n Market Capitalization & \\
\hline $\begin{array}{l}\text { Corporate } \\
\text { governance } \\
\text { (M) }\end{array}$ & CGPI & CGPI score & $\begin{array}{l}\text { Nuswandari, } \\
2009\end{array}$ \\
\hline $\begin{array}{l}\text { Voluntary } \\
\text { disclosure } \\
\text { (Y) }\end{array}$ & VDI & $\begin{array}{l}\text { actual voluntary disclosure } \\
\text { the maximum value of voluntary } \\
\text { disclosure }\end{array}$ & $\begin{array}{l}\text { Darmadi and } \\
\text { Sodikin, } 2013\end{array}$ \\
\hline
\end{tabular}

Source: data processed, 2019 


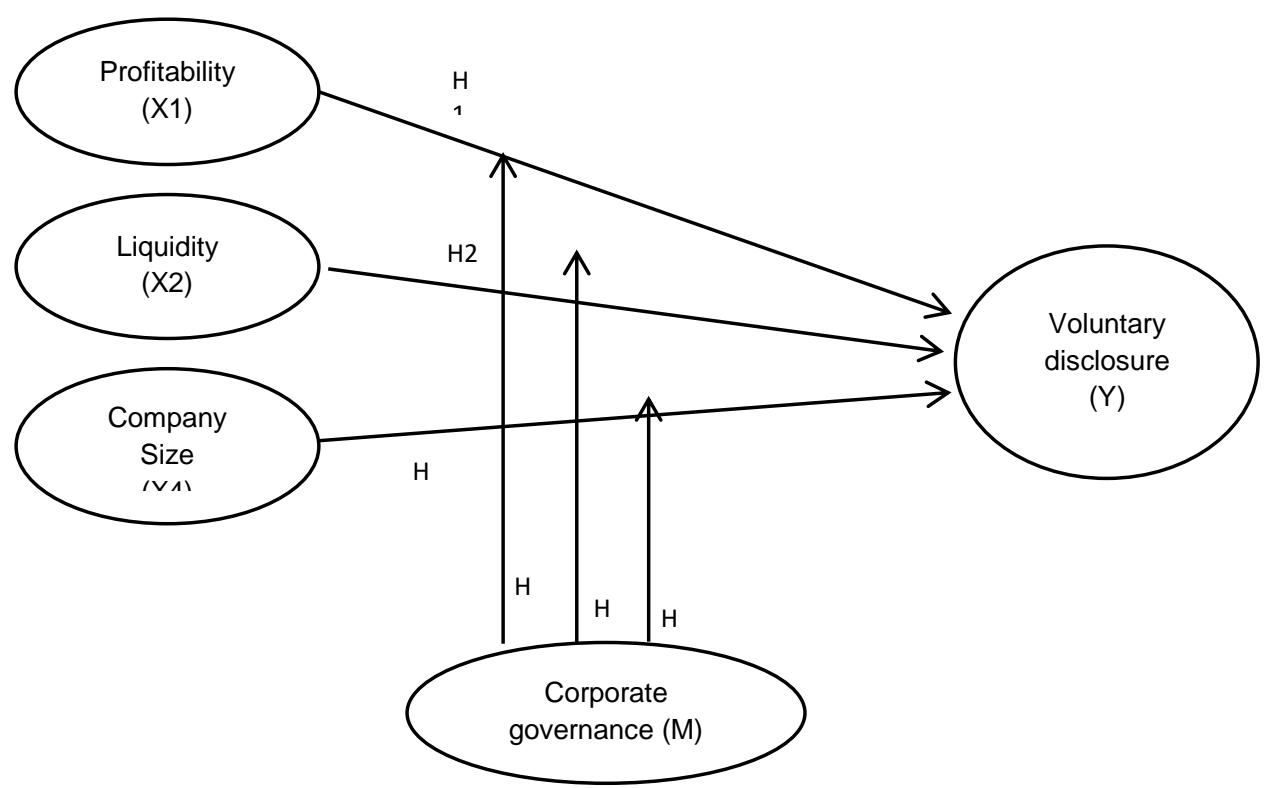

Figure 1: Research Model

The analytical method used in this research is PCA (Principle Component Analysis), which summarizes the information in the original variable (initial) into a new set of dimensions (factors or components) through summarization and reduction (Ghazali, 20018) to obtain independent variables new that can represent each indicator of the independent variable. After PCA analysis, carried out multiple regression analysis, to determine the effect of the independent variables on the dependent and MRA (Moderate Regression Analysis), multiple regression analysis containing the element of interaction (multiplying independent variables with moderating variables). Before the regression test and MRA test were carried out the classical assumption test (normality test, multicollinearity test, autocorrelation test, and heteroscedasticity test). The method of data analysis in this research uses SPSS software.

\section{RESULTS AND DISCUSSION}

Table 2: Descriptive Statistics

\begin{tabular}{|l|l|l|l|l|l|l|l|l|l|l|}
\hline $\begin{array}{l}\text { Variabl } \\
\text { e }\end{array}$ & N & 2012 & 2013 & 2014 & 2015 & 2016 & MIN & MAX & $\begin{array}{l}\text { MEA } \\
\text { N }\end{array}$ & $\begin{array}{l}\text { Stand } \\
\text { ard } \\
\text { Devi } \\
\text { ation }\end{array}$ \\
\hline ROE & 9 & 22,92 & 18,65 & 15,85 & 14,55 & 13,11 & 13,11 & 22,92 & 17,02 & 3,88 \\
\hline ROA & 9 & 6,46 & 4,05 & 3,00 & 2,54 & 2,92 & 2,54 & 6,46 & 3,79 & 1,59 \\
\hline
\end{tabular}




\begin{tabular}{|l|l|l|l|l|l|l|l|l|l|l|}
\hline NPM & 9 & 26,14 & 23,57 & 21,04 & 20,89 & 18,89 & 18,89 & 26,14 & 22,11 & 2,80 \\
\hline $\begin{array}{l}\text { CR/LD } \\
\text { R }\end{array}$ & 9 & $\begin{array}{l}143,9 \\
9\end{array}$ & $\begin{array}{l}114,6 \\
2\end{array}$ & $\begin{array}{l}119,1 \\
4\end{array}$ & $\begin{array}{l}145,3 \\
5\end{array}$ & $\begin{array}{l}155,7 \\
5\end{array}$ & $\begin{array}{l}114,6 \\
2\end{array}$ & $\begin{array}{l}155,7 \\
5\end{array}$ & $\begin{array}{l}135,7 \\
7\end{array}$ & 17,91 \\
\hline $\begin{array}{l}\text { QR/LA } \\
\text { R }\end{array}$ & 9 & $\begin{array}{l}107,8 \\
7\end{array}$ & 82,84 & 86,86 & $\begin{array}{l}111,0 \\
8\end{array}$ & $\begin{array}{l}125,6 \\
1\end{array}$ & 82,84 & $\begin{array}{l}125,6 \\
1\end{array}$ & $\begin{array}{l}102,8 \\
5\end{array}$ & 17,80 \\
\hline $\begin{array}{l}\text { CASR/ } \\
\text { QR }\end{array}$ & 9 & 52,60 & 29,94 & 33,70 & 58,02 & 63,99 & 29,94 & 63,99 & 47,65 & 15,06 \\
\hline TP & 9 & 30,67 & 30,83 & 31,01 & 31,13 & 31,23 & 30,67 & 31,23 & 30,98 & 0,23 \\
\hline TA & 9 & 33,13 & 33,26 & 33,41 & 33,52 & 33,66 & 33,13 & 33,66 & 33,40 & 0,21 \\
\hline KP & 9 & 32,02 & 32,00 & 32,37 & 32,31 & 32,48 & 32,00 & 32,48 & 32,23 & 0,21 \\
\hline CGPI & 9 & 85,61 & 85,89 & 86,91 & 87,30 & 87,69 & 55,32 & 61,81 & 59,26 & 2,68 \\
\hline VDI & 9 & 55,32 & 58,10 & 59,49 & 61,57 & 61,81 & 85,61 & 87,69 & 86,68 & 0,90 \\
\hline
\end{tabular}

Source: Data processed from SPSS, 2019

Table 3: Multiple Regression Test Results

\begin{tabular}{|l|l|l|l|}
\hline Variable & Regression Coefficient & t Value & t Significance \\
\hline (constanta) & 59,259 & 75,643 & 0,000 \\
\hline Profitability & $-4,690$ & $-4,738$ & 0,000 \\
\hline Liquidity & 3,472 & 2,703 & 0,010 \\
\hline Company Size & 4,473 & 3,793 & 0,000 \\
\hline R square & 0,428 & \\
\hline Adj. R Square & 0,371 & \\
\hline F test & 7,491 & \\
\hline Significant F & 0,000 & \\
\hline
\end{tabular}

Source: Data processed from SPSS, 2019

Table 4: Moderation Regression Test

\begin{tabular}{|l|l|l|l|}
\hline Variable & $\begin{array}{l}\text { Regression } \\
\text { Coefficient }\end{array}$ & t Value & $\begin{array}{l}\mathrm{t} \\
\text { Significance }\end{array}$ \\
\hline (constant) & 59,190 & 75,571 & 0,000 \\
\hline Profitability_cgpi & $-0,055$ & $-4,713$ & 0,000 \\
\hline Liquidity_cgpi & 0,042 & 2,750 & 0,009 \\
\hline Company Size_cgpi & 0,052 & 3,822 & 0,000 \\
\hline R square 0,429 & \\
\hline Adj. R Square 0,372 & \\
\hline F test & & \\
\hline Significant F & 0,512 & \\
\hline
\end{tabular}

Source: Data processed from SPSS, 2019

Table 5: Summary of Research Results

Vol. 28, No. 01 April 2020

(C) Centre for Indonesian Accounting and Management Research

Postgraduate Program, Brawijaya University 


\begin{tabular}{|c|c|c|c|c|c|}
\hline $\begin{array}{l}\text { Regression } \\
\text { Model }\end{array}$ & Variable & $\begin{array}{l}\text { Regression } \\
\text { Coefficient }\end{array}$ & $\mathrm{H}$ & $\begin{array}{l}\text { Research } \\
\text { Hypothesis } \\
\text { Test Results }\end{array}$ & Conclusion \\
\hline \multirow{4}{*}{$\begin{array}{l}\text { Model } 1 \\
\text { (Before } \\
\text { being } \\
\text { moderated) }\end{array}$} & Constant & 59,259 & & - & \\
\hline & Profitability & $-4,690$ & H1 & $\begin{array}{l}\mathrm{b} \neq 0 ; \mathrm{b}<0, \\
\text { significant }\end{array}$ & $\begin{array}{l}\text { Negative } \\
\text { effect }\end{array}$ \\
\hline & Liquidity & 3,472 & $\mathrm{H} 2$ & $\begin{array}{l}\mathrm{b} \neq 0 ; \mathrm{b}>0, \\
\text { significant }\end{array}$ & $\begin{array}{l}\text { Positive } \\
\text { effect }\end{array}$ \\
\hline & Company Size & 4,473 & $\mathrm{H} 3$ & $\begin{array}{l}\mathrm{b} \neq 0 ; \mathrm{b}>0, \\
\text { significant }\end{array}$ & $\begin{array}{l}\text { Positive } \\
\text { effect }\end{array}$ \\
\hline \multirow{4}{*}{$\begin{array}{l}\text { Model } 2 \\
\text { (After } \\
\text { being } \\
\text { moderated } \\
\text { by CGPI) }\end{array}$} & Constant & 59,160 & & - & - \\
\hline & Profitability*CGPI & $-0,55$ & $\mathrm{H} 4$ & $\begin{array}{l}-0,55>- \\
4,690, \\
\text { significant } \\
\end{array}$ & $\begin{array}{l}\text { Moderator } \\
\text { Strengthens }\end{array}$ \\
\hline & Liquidity*CGPI & 0,042 & H5 & $\begin{array}{l}0,042<3,472, \\
\text { significant }\end{array}$ & $\begin{array}{l}\text { Weakening } \\
\text { Moderator }\end{array}$ \\
\hline & $\begin{array}{l}\text { Company } \\
\text { Size*CGPI }\end{array}$ & 0,052 & H6 & $\begin{array}{l}0,052<4,473, \\
\text { significant }\end{array}$ & $\begin{array}{l}\text { Weakening } \\
\text { Moderator }\end{array}$ \\
\hline
\end{tabular}

Source: Data processed from SPSS, 2019

From table 5 it can be concluded that profitability, liquidity, company size influences voluntary disclosure. Corporate governance is able to moderate the relationship between profitability, liquidity, company size on voluntary disclosure.

\subsection{DISCUSSION}

\subsubsection{Effect of profitability on voluntary disclosures.}

The H1 hypothesis which states that the effect of profitability on voluntary disclosure is accepted. Table 3 shows that profitability has a negative and significant effect on voluntary disclosure with a coefficient of $-4,690$ and a significance value of 0,000 . The regression coefficient of $-4,690$ shows that profitability has a negative effect on the voluntary disclosure of 4,690. The significance value of 0,000 is smaller than the probability value of 0.050 , so the hypothesis which states that the effect of profitability on voluntary disclosure is accepted. Profitability has a negative effect on voluntary disclosure. This means that the higher the profitability of the company, the lower the voluntary disclosure. Managers can hide information when performance is good. High company performance might increase compensation for managers, but on the other hand, the target and expectations of the company in the future will be higher so that managers will try to low profile in the eyes of investors. In addition, it is possible for 
managers to hide information at a time when high profitability is solely for personal gain through insider trading (the stock compensation hypothesis by Healy and Palepu, 2001). Companies with a low level of profitability, on the other hand, are also encouraged to convey more information given that this additional information is expected to attract investors through consistent disclosure of information to the public. In addition, managers make voluntary disclosures when low profitability is due to explain to investors about the reasons for the company's poor performance (the corporate control contest hypothesis by Healy and Palepu, 2001). The results of this research are consistent with the research conducted by Abdureza Asadi (2016).

\title{
3.1.2 Effect of liquidity on voluntary disclosures.
}

Hypothesis $\mathrm{H} 2$ which states that liquidity has an effect on voluntary disclosure is accepted. Table 3 shows that liquidity has an effect on voluntary disclosure with a coefficient of 3.472 and a significance value of 0.010 . The regression coefficient of 3.472 indicates that liquidity has a positive effect on voluntary disclosure of 3.472. The significance value of 0.010 is smaller than the probability value of 0.050 , so the hypothesis that liquidity has a positive effect on voluntary disclosure is acceptable and significant. The results of this research support the theory that when companies are in a good performance (high liquidity), the company will tend to reveal more information. The goal is to get manager compensation and gain the trust of the company owner (agency theory) and signal to creditors to secure their capital to the company (signal theory). The results of this research support the research conducted by Baroko (2007).

\subsubsection{Effect of company size on voluntary disclosure.}

The H3 hypothesis states that the size of the company influencing voluntary disclosure is accepted. Table 3 shows that company size has an effect on voluntary disclosure with a coefficient of 4.473 and a significance value of 0.000 . The regression coefficient of 4.473 indicates that the size of the company has a positive effect on voluntary disclosure of 4.473. A significance value of 0,000 is smaller than the probability value of 0.050 , meaning significant. So the hypothesis that the size of the company influences voluntary disclosure is acceptable. The bigger the company, the more parties involved and interested in the company. Therefore managers will be encouraged to make more voluntary disclosures to meet the need for information regarding the company's performance and prospects. This situation is also supported by the ability of large companies to produce more information at lower costs compared to small companies. The results of this research support the research conducted by Baroko (2007), Almalia (2008), Alshammari (2008), Hammami and Hossain (2009), Mujiono and Nany (2010), Soliman (2013), and Uyar et al (2013).

Almalia (2008) who examines voluntary disclosure of Internet Financial and Sustainability Reporting is aware of the existence of technological factors and qualified employees who are able to encourage more voluntary disclosure of information by large companies. In addition, Mujiono and Nany (2010) and Uyar et

\author{
Vol. 28, No. 01 April 2020 \\ (C) Centre for Indonesian Accounting and Management Research \\ Postgraduate Program, Brawijaya University
}


al (2013) also added the factors of the low cost of making information and product diversification, as well as the wider market as the advantages of large companies compared to small companies. Large companies also face agency costs, political costs, and the need for greater funding. A more voluntary disclosure will be carried out by the company to maintain its reputation and to reduce these large costs (Hammami and Hossain, 2009).

\subsubsection{Corporate governance relationships in moderating the relationship between profitability and voluntary disclosure.}

The H4 hypothesis which states that corporate governance moderates the relationship of profitability with voluntary disclosure is accepted. Table 4 shows that the interaction variable between profitability and corporate governance has a negative effect on voluntary disclosure with a coefficient of -0.055 and a significance value of 0,000 . The regression coefficient of -0.055 indicates that the interaction between profitability and corporate governance has a negative effect on voluntary disclosure of -0.055 . This means that with an increase in the value of $1 \%$ of the interaction variable corporate governance with profitability, the value of voluntary disclosure will decrease by $5.5 \%$. Whereas if the value of interaction between corporate governance and profitability falls by $1 \%$, the value of voluntary disclosure will increase by $5.5 \%$. A significance value of 0,000 is smaller than the probability value of 0.050 , meaning significant. The coefficient of b1 before the moderating variable is negative, after the moderation variable b1 coefficient is negative, where the coefficient value b1 before the moderating variable is smaller than the value of the coefficient b1 after the moderation variable $(-0.4690<-0.055)$, meaning the variable corporate governance can strengthen the relationship between profitability and voluntary disclosure. So the hypothesis that corporate governance moderates the relationship of profitability with voluntary disclosure is acceptable.

In this research, high profitability will have an impact on reducing voluntary disclosure. With the existence of corporate governance interaction, it encourages companies to disclose voluntary disclosures. Profitability has a negative effect on voluntary disclosure. This means that the higher the profitability of the company, the lower the voluntary disclosure. Managers can hide information when performance is good. High company performance might increase compensation for managers, but on the other hand, the target and expectations of the company in the future will be higher so that managers will try to low profile in the eyes of investors. In addition, it is possible for managers to hide information at a time when high profitability is solely for personal gain through insider trading (the stock compensation hypothesis by Healy and Palepu, 2001).

Companies with a low level of profitability, on the other hand, are also encouraged to convey more information given that this additional information is expected to attract investors through consistent disclosure of information to the public. In addition, managers make voluntary disclosures when low profitability is 
due to explain to investors about the reasons for the company's poor performance (the corporate control contest hypothesis by Healy and Palepu, 2001).

If profitability is considered from the quality of the investment, then companies with lower profits will be encouraged to disclose information more broadly to reduce the risk of negative market views on investment quality, so that they can help companies obtain funds at low costs and avoid a decline in stock prices. In addition, companies with low profitability will explain to investors even though the company has low profits, but the company has performed well, such as the welfare of employees and the environment around the company. Therefore, low profitability supported by good corporate governance further encourages managers to disclose company information more broadly to convince all stakeholders concerned.

\subsubsection{Corporate governance relationships in moderating liquidity and voluntary disclosure relationships.}

The H5 hypothesis which states that corporate governance moderates the relationship of liquidity with voluntary disclosure is accepted. Table 4 shows that the interaction variable between liquidity and corporate governance has a positive effect on voluntary disclosure with a coefficient of 0.042 and a significance value of 0.009 less than 0.050 , so it is significant. The regression coefficient of 0.042 indicates that the interaction between liquidity and corporate governance has a positive effect on voluntary disclosure of 0.042 . This means that with an increase in the value of $1 \%$ of the variable corporate governance interaction with liquidity, the value of voluntary disclosure will increase by $4.2 \%$. Whereas if the value of interaction between corporate governance and liquidity falls by $1 \%$, the value of voluntary disclosure will also decrease by $4.2 \%$. Regression coefficient b2 before the existence of a corporate governance variable with after there is a corporate governance variable is both positive and significant, with a regression coefficient before the interaction of corporate governance of 3.472> of the regression coefficient after the interaction of corporate governance, which is equal to 0.042 which means variable corporate governance is able to weaken the relationship between liquidity and voluntary disclosure. So the hypothesis that corporate governance moderates the relationship of liquidity with voluntary disclosure is acceptable.

Companies with high levels of liquidity tend to disclose more information, but with corporate governance, it turns out the company actually reduces information disclosure. This can happen because there is an independent commissioner whose position is still less influential with the board of commissioners and board of directors, so it will tend to follow the decisions of the board of directors and commissioners regarding information disclosure to reduce information disclosure in the interests of management, especially when liquidity is high unemployed). Management will reduce disclosure more because it does not want to be seen as unsuccessful by shareholders.

Vol. 28, No. 01 April 2020

(C) Centre for Indonesian Accounting and Management Research

Postgraduate Program, Brawijaya University 


\subsubsection{Corporate governance relations in moderating the relationship between company size and voluntary disclosure.}

The H6 hypothesis states that corporate governance moderates the relationship between firm size and voluntary disclosure. Table 4 shows that the interaction variable between company size and corporate governance has a positive effect on voluntary disclosure with a coefficient of 0.052 and a significance value of 0.000 less than 0.050 , so it is significant. The regression coefficient of 0.052 indicates that the interaction between company size and corporate governance has a positive effect on voluntary disclosure of 0.052 . This means that with an increase in the value of $1 \%$ of the interaction variable of corporate governance with firm size, the value of voluntary disclosure will increase by $5.2 \%$. Whereas if the value of interaction between corporate governance and company size drops by $1 \%$, the value of voluntary disclosure will also decrease by $5.2 \%$. The coefficient b4 before the existence of moderating corporate governance moderating variable with the same corporate governance variable is positive and significant, where the regression coefficient before the presence of corporate governance moderation variable is 4.473> than the regression coefficient after the moderation variable, namely 0.052 means corporate governance variable weakening the relationship between company size and voluntary disclosure. So the hypothesis that corporate governance moderates the relationship between company size and voluntary disclosure is acceptable.

The size of the company can increase voluntary disclosure, but with corporate governance, it turns out that the company actually reduces voluntary disclosure. This can happen because of institutional ownership, so there is a voice that limits voluntary disclosure. Institutions as majority shareholders assume that voluntary disclosure is not a mandatory thing to do, made possible by institutional shareholders, which is the only thing that must be reported in financial statements as the fulfillment of applicable regulations.

\subsection{CONCLUSION}

This research examines the factors that influence voluntary disclosure with corporate governance as a moderating variable in companies listed on the Stock Exchange for the period 2012-2016 using the Interaction Test method (MRA). The results of this research found that profitability influences voluntary disclosure, influences liquidity on voluntary disclosure, firm size influences voluntary disclosure, the relationship of profitability with voluntary disclosure moderated (strengthened) by corporate governance, the relationship between liquidity and firm size to voluntary disclosure is moderated (weakened) by corporate governance. The results of this research can be used by companies to provide good advice for management. This research can also contribute to further research in the field of financial accounting. 


\section{REFERENCES}

Akhtaruddin, M, Hossain, M.A., Hossain, M. Dan Yao, L. 2009. "Corporate Governance and Voluntary Disclosure Disclosure in Corporate Annual Reports of Malaysian Listed Firms". JAMAR, 7 (1): 1-20

Al-Shammari, B. 2008. "Voluntary Disclosure in Kuwait Corporate Annual Reports". Review of Business Research, 8

Almalia, L.S. 2008. "Factors Affecting Voluntary Disclosure" Internet Financial and Sustainability Reporting. "JAAI, 12 (2): 117-131

Baroko, D.G. 2007. "Determinants of the Voluntary Disclosures in Kenyan Companies Annual Reports". African Journal of Business Management, 1 (5): $113-128$

Bhasin, M.L, Makarov, R.R., and Orazalin, N.S. 2012. "Determinants of Voluntary Disclosure in the Banking Sector: An Empirical Study". International Journal of Contemporary Business Studies, 3 (3): 60-71

Choi, F. D. S. 1973. "Financial Disclosure and Entry to the European capital market". Journal of Accounting Research. Vol. 11 No. 2: 159-175. http://dx.doi.org/10.2307/2490187

Clemente, A.G. and Labat, B.N 2009. "Corporate Governance Mechanisms and Voluntary Disclosure: The Role of Independent Directors in the Boards of Listed Spanish Firms". (www.ucm.es)

Darmadi, S and Sodikin, A. 2013. "Information Disclosure by Family-Controlled Firm: The Role of Board Independence and Institutional Ownership". (www.ssrn.com)

Ebrahimabadi, Ziba and Asadi, Abdorreza. 2016. The Study of Relationship Between Corporate Characteristics and Voluntary Disclosure in Tehran Stock Exchange ". International Business Management, 10 (7): 11701176

Ghozali, Imam. 2018. Application of Multivariate Analysis with IBM SPSS 25 Program. Diponegoro University Publishing Board.

Hammami, H. Dan Hossain, M. 2009. "Voluntary Disclosure in the Annual Report of Emerging Country: The Case of Qatar". Advances in Accounting, incorporating Advances in International Accounting, 25: 255-265

Hardiningsih, Pancawati. 2008. "Analysis of Factors Affecting Voluntary Disclosure Company Annual Reports". Journal of Business and Economics (JBE), 15 (1): 67-69

Healy, P.M. and Palepu K.G. 2001. "Information Asymmetry, Corporate Disclosure, and The Capital Market: A Review of the Empirical Disclosure Literature". Journal of Accounting and Economics. 31 (1-3): 405-440

Jensen, M.C. and Meckling, W. H. 1976. "Theory of the firm: managerial behavior, agency costs, and ownership structure". Journal of Financial Economics, 3 (4): $305-360$ 
Mujiyono and Nany, M. 2010. "Effects of Leverage, Public Shares, Size, and Audit Committee Against the Area of Voluntary Disclosure". Journal of Dynamics Accounting.2 (2): 129-134

Murcia, F. D., and Santos, A.D. 2010. "Determinants of Corporate Voluntary Disclosure in Brazil". (www.ssrn.com)

Nuswandari, C. 2009. "Disclosure of Financial Reporting in the Signaling Theory Perspective". Accounting Study, 1 (1): 48-57

Oktaviani, D. P. 2016. "Determinants of Voluntary Dislocation Levels: Empirical Study on Manufacturing Companies listed on the Indonesia Stock Exchange". Journal of Accounting Science, 9 (2): 243-254

Panjaitan, Evi Meilana. 2016. "Factors influencing the extent of voluntary disclosure in the annual report: Empirical Study of Consumable Goods Industry sector companies listed on the IDX in 2012-2013". JOM Fekon, $3(1)$

Ross, S. A. 1977. "The Determination of Financial Structure: the incentive signaling approach". Belt Journal of Economics, 8 (1): 23-40

Soliman, M.M. 2013. "Firm Characteristics and the Extend of Voluntary Disclosure: The case of Egyp" t. Research Journal of Finance and Accounting, 4 (17): 71-80

Sugiyono. 2011. "Quantitative, Qualitative, and $R \& D$ Research Methods". Bandung. Alfabeta.

Uyar, A., Kilic, M., and Bayyurt, N. 2013. "Association Between Firm Characteristics and Corporate Voluntary Disclosure: Evidence from Turkish Listed Companies. Intangible Capital (IC), 9 (4): 1080-1112 (www.dx.doi.org)

Widjayanti, S. A. Dan Wahidawati. 2017. "The Effect of Corporate Governance Structure and Mechanism on the Compliance Level of IFRS Convergence Disclosure". Journal of Accounting Science and Research, 4 (7)

Queen, D.C.Y., Liu, M., Zhang, X., and Lu, C. 2009. "A Case Study of Voluntary Disclosure by Chinese Enterprises". Asian Journal of Finance \& Accounting, 1 (2): $118-145$ 
88 Factors Affecting Voluntary Disclosure With Corporate Governance.....

Vol. 28, No. 01 April 2020

(C) Centre for Indonesian Accounting and Management Research Postgraduate Program, Brawijaya University 